\title{
QUANTITATIVE EVALUATION OF UNRELATED DIVERSIFICATION OF ENTERPRISE ACTIVITIES
}

\author{
Romualdas Ginevičius \\ Dept of Enterprise Economics and Business Management, Vilnius Gediminas Technical University, \\ Saulètekio al. 11, LT-10223 Vilnius, Lithuania \\ E-mail: romualdas.ginevicius@adm.vgtu.lt \\ Received 12 Dec 2009; accepted 23 Jan 2009
}

\begin{abstract}
Diversification of activities is one of the main strategies of an enterprise. This is a complicated and controversial process. Some consider it to be a perspective approach, while others think that it is too risky and, therefore, unreliable. To solve this problem, diversification of enterprise activities should be measured. A survey of the methods of diversification measurement shows that they are not accurate and do not reflect the real situation. With the increase of diversification of enterprise activities, two parameters, the number of divisions and the relationship between their activities, vary. The indicator of diversification should assess and integrate both parameters. In this process, the effect of each of the above parameters on the organisational structure, determining the outcome of diversification, should be examined. In this environment, the variation in the number of enterprise activities (or their directions) is more important because the establishment of new divisions depends on it. The variation in the relationships between the particular activities does not necessarily lead to the emergence of a new division. The calculations based on the data obtained from Lithuanian construction enterprises show that the indicator of enterprise diversificiation offered in the present paper satisfies all the considered requirements, while the calculations of its values for actual enterprises demonstrate that it may be successfully used in practice.
\end{abstract}

Keywords: diversification, construction enterprises, measurement of diversification.

\section{Introduction}

Lithuania is integrating into the economic system of the West, therefore, its enterprises should become equal partners of foreign companies. To achieve this, they should increase their competitiveness. In theory and practice, competitiveness is often associated with national and international market development. To win and to expand their markets, the companies should adapt themselves to constantly changing environment, and this process should not be passive. Market growth is the result of a general growth and development of the country's economy. Therefore, the companies should extend the scope of activity; otherwise, they could lose their market share and decline. To avoid this, they should maintain the rate of development not lower than that of the market, which would help them to increase or at least keep their positions. Seeking a larger market share has become the basis for developing the competitive ability of a company.

One of the major strategies of enterprise development is the diversification of its activities (DA). This process is rather complicated and controversial. There are several controversial approaches to the concept of diversification. Some researchers believe that diversification of enterprise activities is a highly promising perspective of its development, which could ensure its long-term financial stability, while others think that it is too complicated and risky to be reliable (Ginevičius 1998).
To solve this problem, diversification of enterprise activities should be measured. Quantitative evaluation of diversification is one of the main problems attracting the researchers. A diversity of measures suggested shows that there is hardly any single approach which could be widely accepted. The aim of the present research is to offer a method of measuring enterprise diversification which could be free of the most of the drawbacks characteristic of the existing approaches.

\section{A review of diversification methods used by the considered enterprises}

Enterprise diversification measures should take into account the nature and forms of this process (Bühner and Spindler 1986). The analysis shows that each of the forms may be referred to the related or unrelated diversification. The main factor determining the type of diversification as related or unrelated is the 'core' of enterprise capabilities, implying its overall capacity to effectively combine the knowledge of the market with the aims of technological development, as well as getting profit and adapting itself to the environment (Wrigley 1970). The related diversification means the extending the scope of enterprise production to the area of manufacture or sale of products which are in the range of the 'core' zone of enterprise capabilities. Unrelated diversification implies, on the contrary, the inclusion of such products in the production 
programme which require for their manufacture capabilities lying outside the 'core' zones of the enterprise.

Under the conditions of increasing market globalization and competition between enterprises, the latter, seeking to increase their profit and ensure long-term financial stability, are striving to decrease the negative effect, produced by the uneven development of one of their activities, on the others. This can be achieved by entering distant markets, not related with each other. Therefore, measuring the unrelated enterprise diversification is an important problem.

All methods of quantitative evaluation of diversification of enterprise activities may be divided into 2 groups. The first group embraces the indicators based on evaluating of the amount of the areas of enterprise activities, while the second includes indicators based on evaluation of the number of areas of activities and the variation in their volumes of work (turnover).

The use of the criteria of group 1 is limited for several reasons. First, it is rather difficult to differentiate between the areas of enterprise activities. Second, the number of the areas of activities does not take into consideration their significance for the turnover and profit of an enterprise (Bühner 1985; Wolf 1995a, b).

To decrease the effect of the drawbacks of the above criteria on the analysis, it was offered to measure the enterprise diversification level based on the generally accepted classification of business areas (Bühner 1985; Wolf 1995a, b). The US Standard Industrial Classification - SIS, representing the industrial structure as a decimal system, was taken as a basis. Based on this and similar classifications, a system of 8 indicators referred to as Gort index, which can be used for determining the significance of both 'major' and 'minor' branches of industry, products, etc., has been offered (Gort 1962).

This set of criteria describing enterprise diversification also has a number of disadvantages. First, the problem of business area identification arises. Second, researchers face another important problem associated with the use of different classification systems for calculation. In addition, differences in the time of evaluation and the 'depth' of classification of various systems make the comparison of the results obtained a complicated problem.

The third group of diversification criteria includes those based on determining the significance of particular areas of enterprise activities. The supporters of the above approach to diversification measuring associate it with the measurement units of the first group. However, they are searching for ways of eliminating their drawbacks. The method suggested includes the evaluation of the significance of areas of activities in addition to their number. In this case, diversification indicator is described by the following expression (Coley and Reinton 1988):

$$
D=\sum_{n=1}^{n} W_{i} P_{i}
$$

where $D$ is diversification index; $P_{i}$ - relative turnover of $i$-th area of activities; $W_{i}$ - the significance of $i$-th activity area; $n$ - the number of areas of activities.
Index $D$ acquires zero value for non-diversified enterprise. When the level of diversification is growing, its value approaches one.

The weak point of index $D$ is its strong dependence on the significance of activity areas.

To strengthen it, the attempt to evaluate the significance of particular areas of activities was abandoned and their relative size (turnover) was weighted 'against itself'. In this way, the so-called Berry index $D_{B}$ (Berry 1971) was obtained:

$$
D_{B}=1-D_{H}=1-\sum_{i=1}^{n} P_{i}^{2},
$$

where $D_{H}$ is Herfindahl concentration index (Wolf 1995a, b; Herfindahl 1950). $\operatorname{dex} D$.

The nature of $D_{H}$ variation is the same as that of in-

When there is no variation in turnover of particular areas of activities, index $D_{B}$ may be calculated by the formula:

$$
D_{B}=1-\frac{1}{n} \text {. }
$$

In some countries, Utton's measure of diversification $W_{U}$ is widely used (Utton 1977):

$$
W_{U}=2 \sum_{i=1}^{n} i P_{i}-1
$$

The indicator $W_{U}$ is the weighted average value of relative amount of products manufactured in the area of enterprise activities. When $W_{U}>1$, it means that we have a specialized enterprise, while, when, for example, $W_{U}=4$, an enterprise is diversified, operating equally well in 4 areas.

There are also less accurate methods of determining diversification level of enterprise, taking into account the significance of various areas of activities. For example, the indicator $D_{\mathrm{p}}$ is based on the turnover of 5 largest areas of activities (Franko 1974):

$$
D_{p}=1000-10 P_{1}-8 P_{2}-6 P_{3}-4 P_{4}-2 P_{5},
$$

where $P_{1}-P_{5}$ denote the percentage of area's turnover of overall turnover.

This measure ensures that, given the same number of areas of activities, the diversification level will be higher at the enterprise, where the turnover is evenly distributed among them.

\section{A measure suggested for determining unrelated diversification of enterprise activities}

All methods used for determining the level of enterprise diversification which were described above have a common drawback - they lack basic consistent methodological principles. As mentioned above, diversification as strategy of enterprise development and expansion aims to adapt it to the environment. It follows from the organization theory that adaptation to the environment (situation) means certain changes in the organisational management structure (Ginevičius 1995; Kieser and Kubicek 1992). The outcome of diversification is also the change in the 
enterprise structure, since the extension of the range of products and areas of activities, as well as geographical changes, lead to the establishment of new divisions. Therefore, raising of diversification level causes the variation of 2 parameters - the number of enterprise divisions and the relationship between the volumes of work performed by their staff. To analyse diversification from various perspectives, both parameters should be integrated and adequately evaluated. This means that the effect of the above parameters on the organisational structure of an enterprise should be taken into consideration. In this sense, the change in the number of directions of enterprise activities is more important, since it leads to the formation of new divisions. The variation between the particular businesses is not always the cause of the emergence of a new division (Ginevičius and Petraškevičius 2008).

Therefore, the suggested diversification indicators should be revised taking into account the above considerations.

Gort indices' imperfections are associated with the fact that they rely on the limited classification systems and do not cover all areas of enterprise activities. Moreover, they do not take into consideration the variation in their turnover.

Now, the most widely used Berry index should be analysed to identify its strengths and weaknesses. Calculations performed for different diversification levels show that:

1. Berry index used for determining diversification level takes into account only one quantity, associated with not most essential parameter - the variation in turnover. Another important parameter - the number of the areas of activities is assessed only indirectly via the variation in turnover.

2. Berry index is most sensitive, implying that it can determine diversification level most accurately, but only in the cases when the number of activities is small (not more than 2), and the variation between their turnover is high. When these parameters are changing, i.e. the number of enterprise activity areas is growing, while the variation in their turnover is decreasing, the sensitivity of Berry index is also decreasing. However, this situation is most probable because enterprises are striving to reduce the variation between different areas of activities; otherwise, the effectiveness of diversification investment projects could decrease and management costs could increase.

A methodological principle underlying Berry index does not seem to be reliable either because it is obtained by subtracting one from the value of Herfindahl concentration index. This approach is very specific in determining the significance of activity areas and a measure used can hardly reflect the real situation because, in this case, areas of activities with the largest turnover are assigned disproportionally high significance values (weights) (Häne 1987). It follows that the values of concentration and diversification indices depend on the areas of activities with large turnover (Ginevičius, Čirba 2007). Areas of activities with small turnover, even if their number is large, have actually no influence on the results. Moreover, a question arises if the significance of particular areas of activities should be taken into account in quantitative evaluation of enterprise diversification, contrary to market concentration. In fact, diversification index should adequately reflect the situation and take into consideration only the number of enterprise areas of activities and the variation in their turnover.

Therefore, seeking to improve methods of evaluating enterprise diversification strategy, an effort was made to offer indicators which take into consideration both parameters of the organization structure, i.e. the variation in areas of activities and their turnover, focusing, however, on the first parameter as better reflecting the changes in the organisational management structure caused by its diversification. As a result, the following indicator (Ginevičius 1997, 1998) was suggested:

$$
D_{R}^{\prime}=\frac{n+(n-1) \sum_{i=1}^{n} \frac{P_{i}}{P_{\max }}}{n},
$$

where $D_{R}^{\prime}$ is the indicator of enterprise diversification; $P_{\max }$ - the relative turnover of the largest area of activities.

The application of the diversification indicator of this form is limited because the range of its variation is not defined as, for example, is the case with the index $D_{B}$. Therefore, the comparison of these 2 indices is complicated. This difficulty can be overcome by transforming $D_{B}$ as follows:

$$
D_{R}=1-\frac{n}{n+(n-1) \sum_{i=1}^{n} \frac{P_{i}}{P_{\max }}},
$$

where $D_{R}$ is the diversification index of enterprise activities.

As shown in formula (6), in the absence of variation in turnover between the areas of activities, $D_{G}=1-\frac{1}{n}$ (same as for $D_{B}$ ). When the variation starts growing, $D_{G}$ is approaching the value of $1-\frac{n}{2 n-1}$. It follows that the variation limits of diversification index $D_{R}$ are expressed as

$$
1-\frac{n}{2 n-1} \leq D_{R} \leq 1-\frac{1}{n} .
$$

We can see in formula (7) that, when $n$ is approaching 1 , the value of $D_{R}$ approaches zero, while when $n$ is increasing, the value of $D_{G}$ approaches one.

The diversification level of enterprise activities expressed as the number of areas of activities may be determined by formula (5).

More exhaustive analysis of diversification index $D_{G}$ revealed its weak points. The main imperfection is associated with the excessive focusing on the influence of the number of areas of enterprise activities on the index value. For example, even when one of the two activity 
areas has almost all enterprise turnover, the value of $D_{G}$ will not be smaller than 0.33 . It is evident that the real view is distorted.

Diversification index should be based on the assumption that, in the absence of variation in activity areas' turnover, i.e. when $P_{i}=P_{i+1}$, the index value is equal to $D_{B}(3)$.

For the fixed number of areas of activities it is the lowest index value.

Variation in turnover between the areas of enterprise activities and its growth should affect $n$ because, at the fixed number of activities, it means the increase of turnover in some particular areas and its decrease in others. In this case, the concentration of production is taking place, implying that the diversification level is getting lower. Variation cannot be evaluated based on the ratio of turnover of one area of activities to another because the data obtained would not be correct. For example, let us consider 2 examples of diversification strategy. In the first case, 2 areas of activities account for $50 \%$ of the total enterprise turnover each, i.e. $P_{1}=0.5$ and $P_{2}=0.5$. In the second case, we have 6 areas of activities: $P_{1}=0.5 ; P_{2}=$ $0.1 ; P_{3}=0.1 ; P_{4}=0.1 ; P_{5}=0.1 ; P_{6}=0.1$. Let us calculate the variation by the formula $V=\sum_{i=1}^{n} \frac{P_{i}}{P_{\max }}$. In both cases, we will get that $V=2$. It follows that the extent of variation may be determined much more precisely based on the differences in turnover between the areas of activities; for example, $P_{\max }-P_{i}$. In this case, for the examples considered $V_{1}=0$, while $V_{2}=1.6$. Taking this into consideration, the following formula may be suggested for enterprise diversification:

$$
D_{G}=1-\frac{1}{\sum_{i=1}^{n} \frac{1-q_{\max }}{1-q_{i}}},
$$

where $D_{G}$ - the suggested indicator of enterprise activity diversification.

To provide more weighty arguments for applicability of indices $D_{B}$ and $D_{G}$ and their valuable characteristics, they should be compared based on consideration of typical variants of the production programme of an enterprise. First, let us demonstrate the nature of variation of these indices, when the variation in turnover between areas of activities is uniformly decreasing, while their number is uniformly increasing. This is reflected by the data presented in Table 1.

Based on the data presented in Table 1, graphical representation of the variation of values of indices $D_{B}$ and $D_{G}$ is provided in Fig. 1.

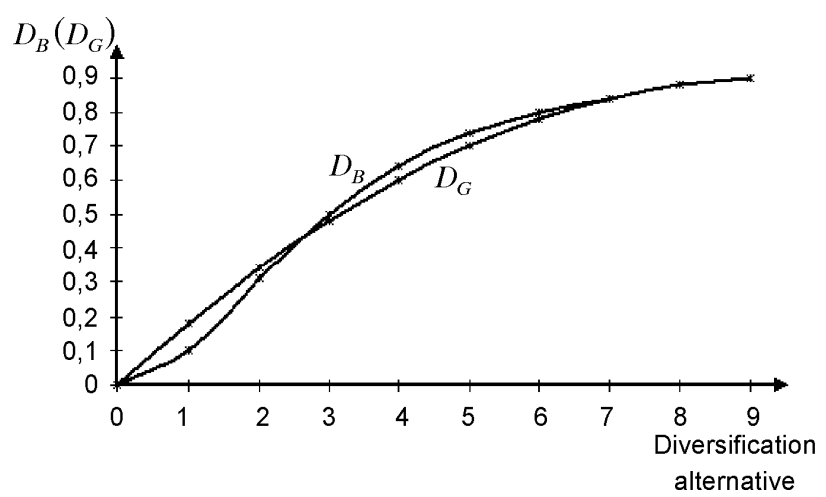

Fig. 1. The variation of enterprise diversification indices when variation in turnover of a particular activity area is uniformly decreasing, while the number of activities is uniformly increasing

Now, let us determine the nature of variation in enterprise diversification indices $D_{B}$ and $D_{G}$ depending only on the variation in turnover. This may be performed based on the data presented in Table 2 .

The range of variation of enterprise diversification indices $D_{B}$ and $D_{G}$ for the case, when the number of activity areas remains unchanged while their turnover is uniformly changing is defined by $\Delta k$ :

$$
\Delta k_{i}=\frac{k_{\max i}}{k_{\min i}},
$$

where $\Delta k_{i}$ is the relationship between the values of diversification index, when the number of activity areas is equal to $i ; k_{\max i}$ is the largest value of diversification index, when the number of activity areas is equal to $i ; k_{\min i}$ is the smallest value of $i$.

The values of $\Delta k_{i}$ determined based on the data presented in Table 2 are given in Table 3 .

Table 1. The values of enterprise diversification indices $D_{B}$ and $D_{G}$ depending on uniform variation in the number of activities and turnover

\begin{tabular}{c|c|c|c|c|c|c|c|c|c|c|c|c}
\hline $\begin{array}{c}\text { Enter- } \\
\text { prise } \\
\text { No. }\end{array}$ & \multicolumn{9}{|c|}{ Diversification alternative of enterprise production programme (relative turnover) } & \multicolumn{4}{c}{$\begin{array}{c}\text { Values of diversification } \\
\text { indices }\end{array}$} \\
\cline { 2 - 16 } & 1 & 2 & 3 & 4 & 5 & 6 & 7 & 8 & 9 & 10 & $D_{B}$ & $D_{G}$ \\
\hline & 1.0 & & & & & & & & & & 0.00 & 0.00 \\
\hline 1 & 0.9 & 0.1 & - & - & - & - & - & - & - & - & 0.18 & 0.10 \\
\hline 2 & 0.8 & 0.1 & 0.1 & - & - & - & - & - & - & - & 0.34 & 0.31 \\
\hline 3 & 0.7 & 0,1 & 0.1 & 0.1 & - & - & - & - & - & - & 0.48 & 0.50 \\
\hline 4 & 0.6 & 0.1 & 0.1 & 0.1 & 0.1 & - & - & - & - & - & 0.60 & 0.64 \\
\hline 5 & 0.5 & 0.1 & 0.1 & 0.1 & 0.1 & 0.1 & - & - & - & - & 0.70 & 0.74 \\
\hline 6 & 0.4 & 0.1 & 0.1 & 0.1 & 0.1 & 0.1 & 0.1 & - & - & - & 0.78 & 0.80 \\
\hline 7 & 0.3 & 0.1 & 0.1 & 0.1 & 0.1 & 0.1 & 0.1 & 0.1 & - & - & 0.84 & 0.84 \\
\hline 8 & 0.2 & 0.1 & 0.1 & 0.1 & 0.1 & 0.1 & 0.1 & 0.1 & 0.1 & - & 0.88 & 0.88 \\
\hline 9 & 0.1 & 0.1 & 0.1 & 0.1 & 0.1 & 0.1 & 0.1 & 0.1 & 0.1 & 0.1 & 0.90 & 0.90 \\
\hline
\end{tabular}


Table 2. Diversification alternatives of enterprise production programme for the constant number of areas of activities

\begin{tabular}{|c|c|c|c|c|c|c|c|c|c|c|}
\hline \multirow{2}{*}{$\begin{array}{l}\text { Number of } \\
\text { activities }\end{array}$} & \multicolumn{8}{|c|}{ Diversification alternatives of enterprise production programme (relative turnover) } & \multicolumn{2}{|c|}{$\begin{array}{l}\text { Values of diversifica- } \\
\text { tion indices }\end{array}$} \\
\hline & 1 & 2 & 3 & 4 & 5 & 6 & 7 & 8 & $D_{B}$ & $D_{G}$ \\
\hline \multirow{5}{*}{ Two } & 0.9 & 0.1 & - & - & - & - & - & - & 0.18 & 0.10 \\
\hline & 0.8 & 0.2 & - & - & - & - & - & - & 0.34 & 0.20 \\
\hline & 0.7 & 0.3 & - & - & - & - & - & - & 0.42 & 0.30 \\
\hline & 0.6 & 0.4 & - & - & - & - & - & - & 0.48 & 0.40 \\
\hline & 0.5 & 0.5 & - & - & - & - & - & - & 0.50 & 0.50 \\
\hline \multirow{9}{*}{ Four } & 0.9 & 0.033 & 0.033 & 0.033 & - & - & - & - & 0.19 & 0.24 \\
\hline & 0.8 & 0.067 & 0.067 & 0.067 & - & - & - & - & 0.35 & 0.39 \\
\hline & 0.7 & 0.100 & 0.100 & 0.100 & - & - & - & - & 0.48 & 0.50 \\
\hline & 0.6 & 0.133 & 0,133 & 0.133 & - & - & - & - & 0.59 & 0.58 \\
\hline & 0.5 & 0.167 & 0.167 & 0.167 & - & - & - & - & 0.67 & 0.64 \\
\hline & 0.4 & 0.200 & 0.200 & 0.200 & - & - & - & - & 0.72 & 0.69 \\
\hline & 0.3 & 0.233 & 0.233 & 0.233 & - & - & - & - & 0.75 & 0.73 \\
\hline & 0.2 & 0.267 & 0.267 & 0.267 & - & - & - & - & 0.75 & 0.74 \\
\hline & 0.1 & 0.300 & 0.300 & 0.300 & - & - & - & - & 0.72 & 0.74 \\
\hline \multirow{9}{*}{ Eight } & 0.9 & 0.014 & 0.0143 & 0.0143 & 0.0143 & 0.0143 & 0.0143 & 0.0143 & 0.19 & 0.42 \\
\hline & 0.8 & 0.029 & 0.029 & 0.029 & 0.029 & 0.029 & 0.029 & 0.029 & 0.35 & 0.59 \\
\hline & 0.7 & 0.043 & 0.043 & 0.043 & 0.043 & 0.043 & 0.043 & 0.043 & 0.50 & 0.69 \\
\hline & 0.6 & 0.057 & 0.057 & 0.057 & 0.057 & 0.057 & 0.057 & 0.057 & 0.62 & 0.75 \\
\hline & 0.5 & 0.071 & 0.071 & 0.071 & 0.071 & 0.071 & 0.071 & 0.071 & 0.71 & 0.79 \\
\hline & 0.4 & 0.086 & 0.086 & 0.086 & 0.086 & 0.086 & 0.086 & 0.086 & 0.79 & 0.82 \\
\hline & 0.3 & 0.100 & 0.100 & 0.100 & 0.100 & 0.100 & 0.100 & 0.100 & 0.84 & 0.84 \\
\hline & 0.2 & 0.114 & 0.114 & 0.114 & 0.114 & 0.114 & 0.114 & 0.114 & 0.87 & 0.86 \\
\hline & 0.1 & 0.129 & 0.129 & 0.129 & 0.129 & 0.129 & 0.129 & 0.129 & 0.87 & 0.87 \\
\hline
\end{tabular}

Table 3. The variation range of enterprise diversification index values for the constant number of activity areas

\begin{tabular}{|c|c|c|c|c|c|c|c|c|}
\hline \multirow{3}{*}{$\begin{array}{l}\text { Number of } \\
\text { activities }\end{array}$} & \multicolumn{4}{|c|}{ Diversification index value } & \multirow{2}{*}{\multicolumn{2}{|c|}{$\begin{array}{l}\text { The value of coefficient } \\
\qquad \Delta k\end{array}$}} & \multirow{3}{*}{ Ratio } & \multirow{3}{*}{$\frac{\Delta k_{D_{B}}}{\Delta k_{D_{G}}}$} \\
\hline & \multicolumn{2}{|c|}{ the smallest } & \multicolumn{2}{|c|}{ the largest } & & & & \\
\hline & $D_{B}$ & $D_{G}$ & $D_{B}$ & $D_{G}$ & $D_{B}$ & $D_{G}$ & & \\
\hline Two & 0.18 & 0.1 & 0.50 & 0.50 & 2.8 & 5.0 & & 0.56 \\
\hline Four & 0.19 & 0.2 & 0.75 & 0.74 & 4.0 & 3.1 & & 1.27 \\
\hline Eight & 0.19 & 0.4 & 0.87 & 0.87 & 4.6 & 2.1 & & 2.18 \\
\hline
\end{tabular}

Table 4. The values of enterprise diversification indices $D_{B}$ and $D_{G}$, when the number of the areas of activities is constantly growing

\begin{tabular}{|c|c|c|c|c|c|c|c|c|c|c|c|c|}
\hline \multirow[t]{2}{*}{$\begin{array}{c}\text { Enter- } \\
\text { prise } \\
\text { No. }\end{array}$} & \multicolumn{10}{|c|}{ Diversification alternatives of enterprise production programme (relative turnover) } & \multicolumn{2}{|c|}{$\begin{array}{c}\text { Values of } \\
\text { diversification } \\
\text { indices }\end{array}$} \\
\hline & 1 & 2 & 3 & 4 & 5 & 6 & 7 & 8 & 9 & 10 & $D_{B}$ & $D_{G}$ \\
\hline 1 & 0.9 & 0.1 & - & - & - & - & - & - & - & - & 0.1800 & 0.11 \\
\hline 2 & 0.9 & 0.05 & 0.05 & - & - & - & - & - & - & - & 0.1850 & 0.17 \\
\hline 3 & 0.9 & 0.033 & 0.033 & 0.033 & - & - & - & - & - & - & 0.1870 & 0.24 \\
\hline 4 & 0.9 & 0.025 & 0.025 & 0.025 & 0.025 & - & - & - & - & - & 0.1880 & 0.29 \\
\hline 5 & 0.9 & 0.02 & 0.02 & 0.02 & 0.02 & 0.02 & - & - & - & - & 0.1880 & 0.34 \\
\hline 6 & 0.9 & 0.0167 & 0.0167 & 0.0167 & 0.0167 & 0.0167 & 0.0167 & - & - & - & 0.1881 & 0.38 \\
\hline 7 & 0.9 & 0.0143 & 0.0143 & 0.0143 & 0.0143 & 0.0143 & 0.0143 & 0.0143 & - & - & 0.1886 & 0.42 \\
\hline 8 & 0.9 & 0.0125 & 0.0125 & 0.0125 & 0.0125 & 0.0125 & 0.0125 & 0.0125 & 0.0125 & - & 0.1888 & 0.45 \\
\hline 9 & 0.9 & 0.0111 & 0.0111 & 0.0111 & 0.0111 & 0.0111 & 0.0111 & 0.0111 & 0.0111 & 0.0111 & 0.1889 & 0.48 \\
\hline
\end{tabular}

The data presented in Table 3 confirm the statement that diversification index $D_{B}$ is more sensitive to the variation in turnover of activity areas than index $D_{G}$.

In addition to the analysis of sensitivity of the above two diversification indices to turnover variation, their sensitivity to the variation in the number of activity areas should be examined. For this purpose, the data presented in Table 4 may be used.

In Fig. 2, graphical representation of the variation in values of diversification indices $D_{B}$ and $D_{G}$, when the number of activity areas is constantly growing, is given based on the data provided in Table 4.

As shown in Table 4 and Fig. 2, the index $D_{G}$ is much more sensitive to the variation in the number of activity areas. The ratio of its largest values to its smallest values calculated by formula (8) shows that, when the number of activity areas increases from 2 to 10 , the value of $D_{B}$ grows by 1.05 times or $5 \%$, while the value of $D_{G}-$ by 4.8 times or $48 \%$. Taking into account that the changes in enterprise management structure are primarily 
Table 5. The values of diversification indicators $D_{B}$ and $D_{G}$ of construction enterprise activities

\begin{tabular}{|c|c|c|c|c|c|c|c|c|c|c|c|}
\hline \multirow{2}{*}{$\begin{array}{c}\text { Enterprise } \\
\text { No }\end{array}$} & \multicolumn{8}{|c|}{ Relative turnover of the activity areas of enterprises } & \multicolumn{2}{|c|}{$\begin{array}{c}\text { Diversification } \\
\text { index value }\end{array}$} & \multirow[t]{2}{*}{$\left(D_{B}-D_{G}\right)$} \\
\hline & 1 & 2 & 3 & 4 & 5 & 6 & 7 & 8 & $D_{B}$ & $D_{G}$ & \\
\hline 1 & 0.969 & 0.005 & 0.026 & - & - & - & - & - & 0.06 & 0.06 & 0 \\
\hline 2 & 0.959 & 0.008 & 0.033 & - & - & - & - & - & 0.08 & 0.08 & 0 \\
\hline 3 & 0.981 & 0.014 & 0.005 & - & - & - & - & - & 0.04 & 0.04 & 0 \\
\hline 4 & 0.376 & 0.027 & 0.597 & - & - & - & - & - & 0.50 & 0.51 & 0.01 \\
\hline 5 & 0.964 & 0.013 & 0.023 & - & - & - & - & - & 0.07 & 0.07 & 0 \\
\hline 6 & 0.311 & 0.074 & 0.615 & - & - & - & - & - & 0.52 & 0.49 & 0.03 \\
\hline 7 & 0.122 & 0.087 & 0.523 & 0.268 & - & - & - & - & 0.63 & 0.63 & 0 \\
\hline 8 & 0.701 & 0.187 & 0.074 & 0.038 & - & - & - & - & 0.47 & 0.50 & 0.03 \\
\hline 9 & 0.811 & 0.145 & 0.015 & 0.029 & - & - & - & - & 0.32 & 0.29 & 0.03 \\
\hline 10 & 0.831 & 0.036 & 0.115 & 0.018 & - & - & - & - & 0.30 & 0.35 & 0.05 \\
\hline 11 & 0.112 & 0.188 & 0.532 & 0.078 & 0.023 & 0.067 & - & - & 0.66 & 0.72 & 0.06 \\
\hline 12 & 0.927 & 0.014 & 0.006 & 0.014 & 0.014 & 0.004 & 0.001 & 0.020 & 0.14 & 0.34 & 0.20 \\
\hline 13 & 0.699 & 0.009 & 0.214 & 0.033 & 0.007 & 0.005 & 0.018 & 0.015 & 0.46 & 0.69 & 0.23 \\
\hline
\end{tabular}

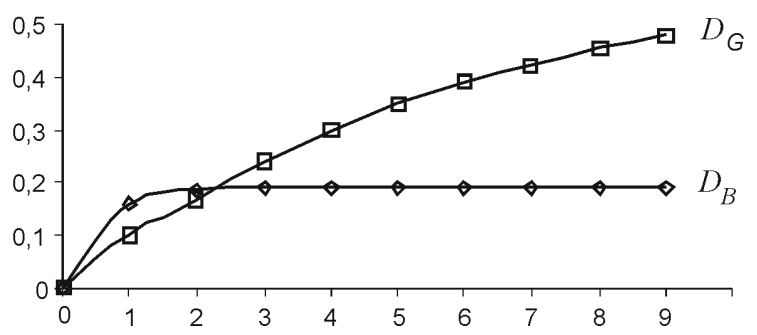

Fig. 2. The variation in the values of diversification indices $D_{B}$ and $D_{G}$, when the number of activity areas is constantly growing

reflected by the number of enterprise areas of activities, it may be stated that index $D_{G}$ is better suited for describing enterprise diversification.

The applicability of the index $D_{G}$ to the analysis of enterprise diversification can be shown by examining the results obtained in calculating its value for actual enterprises. The data on their performance and calculation results are given in Table 5. It can be seen that the larger the number of the areas of enterprise activities, the greater the difference between the values of the above indices.

For example, the differences for enterprises 12 and 13, extending their activities to 8 areas, are the highest 0.2 and 0.23 , respectively. The difference for enterprise 11 , diversifying into 6 areas, is only 0,06 . For enterprises $7,8,9$ and 10 , extending the activities to 4 areas, the above difference is $0 ; 0.03 ; 0,03$ and 0.05 , respectively. For enterprises, diversifying into 3 areas of activities, the values of diversification indices and differences between them are still smaller. This shows that the philosophy of index $D_{G}$ development more precisely reflects the actual processes.

\section{Conclusions}

The analysis of the enterprise performance indices shows that all of them have certain imperfections. Some of them pay too much or too little attention to the significance of particular areas of activities, others are not accurate and cannot be compared because of their specific form, etc.
The most widely used Berry index gives the priority to turnover variation between particular areas of activities. The suggested diversification index is free from these defects. It gives the priority to the effect of diversification on the organisational management structure because the worldwide experience shows that it causes changes in the enterprise structure, making it divisional rather than functional. The lack of changes in management structure or inappropriate changes are the major causes of failure of enterprise diversification projects.

The index offered in the present paper satisfies all the requirements discussed above and, therefore, may be successfully used in practice.

\section{References}

Berry, Ch. 1971. Corporate growth and industrial diversification, Journal of Law and Economics 14: 371-383.

Bühner, R. 1985. Strategie und organisation. Wiesbaden, Gabler.

Bühner, R.; Spindler, H. J. 1986. Synergieerwartungen bei Unternehmenszusammenschlüssen, Die Betrieb 39(12): 601-606.

Coley, S. C.; Reinton, S. E. 1988. The hunt for value. The Mc Kinley Quarterly.

Franko, L. G. 1974. The move toward multidimensional structure in European organisation, Administrative Science Quarterly 19: 493-506.

Ginevičius, R. 1995. Situational analysis and formation of organisational management structures of construction enterprises. Vilnius: Technika.

Ginevičius, R. 1997. Quantitative evaluation of diversification of commercial and economic activities of the construction enterprise, in Vedecka konference ustavu u kateder konstrukci pozemnych staveb: sbornik. Čejkovice (Čekija) Brno, 59-62.

Ginevičius, R. 1998. Diversification of enterprise activities. Vilnius: Technika.

Ginevičius, R.; Petraškevičius, V. 2008. Some problems of measuring enterprise diversification, Verslas: teorija ir praktika [Business: Theory and Practice] 9(3): 215-220.

Ginevičius, R.; Čirba, S. 2007. Determining market concentration, Journal of Business Economics and Management 8(1): 3-10. 
Gort, M. 1962. Diversification and integration in American industry. Princeton.

Häne, P.-K. 1987. Die Messung der Unternehmenskonzentration: eine theoretische und empirische Evolution von Konzentrationsmaßen. Diss. Verlag Rüegger.

Herfindahl, O. C. 1950. Concentration in the steel industry. Columbia University.

Kieser, A.; Kubicek, H. 1992. Organization. 3. Völlig neu Bearb. Aufl. Berlin, New York: de Gruyter.
Utton, M. M. 1977. Large firm diversification in british manufacturing industry, Economic Journal 87: 6-11.

Wolf, J. 1995a. Die Messung des Diversifikationsgrads von Unternehmen (I), Wirtschaltsstudium 5: 439-445.

Wolf, J. 1995b. Die Messung des Diversifikationsgrads von Unternehmen (II), Wirtschaltsstudium 6: 519-523.

Wrigley, L. 1970. Divisional autonomy and diversification. Harvard Business School Boston.

\section{IMONIŲ VEIKLOS NESUSIJUSIOS DIVERSIFIKACIJOS KIEKYBINIS IৃVERTINIMAS}

\section{R. Ginevičius}

\section{Santrauka}

Viena iš pagrindinių i̇monių plètros strategijų - jų veiklos diversifikacija. Šis fenomenas pasižymi dideliu kompleksiškumu, todèl yra gana prieštaringas. Vienais atvejais manoma, kad tai perspektyvus būdas, kitais - kad diversifikacija yra per daug rizikinga, todèl vargu ar prasminga. Norint atsakyti $i$ šiuos klausimus, veiklos diversifikaciją reikia išmatuoti. Matavimo būdų apžvalga rodo, kad jie yra netikslūs ir neatspindi realios padèties. Stiprejant įmonès veiklos diversifikacijai, kinta du i̇monés parametrai - padalinių skaičius ir jų atliekamų darbų santykis. Diversifikacijos rodiklis turi abu šiuos parametrus tinkamai įvertinti ir sujungti. Tai atliekant reikia atsižvelgti i kiekvieno iš šių parametru įtaką organizacinei ¿̨monès struktūrai, svarbiausiam įmonès veiklos diversifikacijai padariniui. Svarbesnis yra įmonès veiklos krypčiu skaičiaus kitimas, nes nuo jo priklauso naujų padalinių atsiradimas. Verslo variacija dar ne visada gali būti naujo padalinio atsiradimo priežastis. Pateikiamas i̇monių veiklos diversifikacijos rodiklis atitinka visus šiuos reikalavimus. Jo reikšmių skaičiavimas realioms įmonèms parode, kad jis gali būti taikomas praktiškai.

Reikšminiai žodžiai: diversifikacija, diversifikacijos matavimas.

Romualdas GINEVIČIUS. Professor, Dr Habil. Head of the Department of enterprise economics and management, construction engineer and economist. The author of more than 350 research papers and over 20 scientific books; editor-inchief of the "Journal of Business Economics and Management" (located in ISI database "Web of Science") and the journal "Business: theory and practice".

Research interests: organization theory, complex quantitative evaluation of social processes and phenomena. 